\title{
Female-biased herbivory in fourwing saltbush browsed by cattle
}

\author{
ANDRÉS F. CIBILS, DAVID M. SWIFT, AND RICHARD H. HART
}

Authors are Research Specialist, School of Renewable Natural Resources, The University of Arizona, Tucson, Ariz.85721, email: acibils@Ag.arizona.edu (on leave form INTA-EEA Santa Cruz, and Universidad Nacional de la Patagonia Austral, Río Gallegos, Argentina); Associate Professor, Rangeland Ecosystem Science Department, and Senior Scientist, Natural Resource Ecology Laboratory, Colorado State University, Fort Collins, Colo. 80523; Rangeland Scientist, USDA-ARS High Plains Grasslands Research Station, Cheyenne, Wyo. 82009. At the time of the research, the senior author was PhD candidate, Rangeland Ecosystem Science Department and Natural Resource Ecology Laboratory, Colorado State University, Fort Collins, Colo.

\begin{abstract}
Female fourwing saltbush (Atriplex canescens Pursh [Nutt.]) shrubs are more abundant in exclosures than in adjacent grazed pastures at our research site on the shortgrass steppe in Colorado. We hypothesized that female shrubs at this site were being browsed more heavily by cattle than were male shrubs. We conducted a series of 2-year experiments (1997 and 1998) with cattle to measure levels of cattle utilization of male and female shrubs. Overall, utilization of marked leaders was $43.5 \%$ in January, $19.7 \%$ in April, and 33.4\% in September. Percent utilization of marked leaders was consistently and significantly higher on female shrubs both in January (females: $\mathbf{4 6 . 5 \%}$, males: $\mathbf{4 0 . 2 \%}$ ), and September (females: $36.9 \%$, males: $29.9 \%$ ). In April, differences in utilization of shrub sexes were not significant (females: 20.3\%, males: $19.2 \%$ ). The female-bias in cattle herbivory increased significantly with increasing overall utilization of shrubs. Gender-biased herbivory may have promoted higher mortality among female shrubs, leading to the sex ratio alteration previously observed at this site.
\end{abstract}

Key Words: Atriplex canescens, cattle-browsing, dioecious shrubs, gender-biased herbivory

Interest in studying patterns of animal-plant interactions in dioecious plants has increased steadily over the past 35 years (Boecklen and Hoffman 1993, Watson 1995), although the subject has received little attention (28 case studies published since 1960) compared to other aspects of plant-herbivore interactions. Whereas male-biased herbivory appears to be the most common pattern (and is therefore assumed to be the rule), a number of studies report the occurrence of no bias or female-biased her-

Research was funded by the Agricultural Research Service of the United States Department of Agriculture, High Plains Grasslands Research Station, Cheyenne, Wyo. The Instituto Nacional de Tecnologia Agropecuaria (Argentina) provided personal support for A. Cibils. Authors wish to express their thanks to Jim Detling, Dave Steingraeber, Bill Lauenroth, and 3 anonymous reviewers who provided helpful comments on earlier versions of this manuscript, and to Mary Ashby, Jeff Thomas, Stan Clapp, Dale Hill, Mike McArtor, and Ernie Taylor who provided valuable help in the field and laboratory.

Manuscript accepted 27 Apr. 02
Resumen

La abundancia de arbustos hembra de Atriplex canescens Pursh [Nutt.] es mayor en clausuras que en potreros pastoreados en nuestro sitio de estudio en la estepa de pastos cortos de Colorado. Se postuló que los arbustos hembra estaban siendo ramoneados mas intensamente por bovinos que los arbustos macho. Se condujeron una serie de experimentos de 2 años de duración (1997 y 1998) para determinar niveles de ramoneo bovino en arbustos hembra y macho. En general, los niveles de utilización medidos sobre tallos marcados fueron de $43.5 \%$ en enero (invierno), $19.7 \%$ en abril (primavera) y $33.4 \%$ en septiembre (verano). El procentaje de utilización de tallos marcados en arbustos hembra fue consistente y significativamente mayor que la utilización registrada en arbustos macho, tanto en enero (hembras: $46.5 \%$; machos: $40.2 \%$ ) como en septiembre (hembras: $36.9 \%$; machos: $29.9 \%$ ). En abril dichas diferencias no fueron significativas ( hembras: $20.3 \%$; machos:19.2\%). El sesgo femenino de hebivoría tendió a acentuarse con niveles crecientes de intensidad de ramoneo bovino. Dicho sesgo podría haber promovido mayores tasas de mortalidad en arbustos hembra provocando la alteración de proporciones de sexos de la población de arbustos observada previamente en este sitio.

bivory (Graetz 1978, Williams et al. 1978, Lovett Doust and Cavers 1982, Lovett Doust and Lovett Doust 1985, Danell et al. 1985, Alliende 1989, Boecklen et al. 1990, Krischik and Denno 1990, Danell et al. 1991, Hjalten 1992, Maywald 1998, Maywald et al. 1998).

We conducted our research in a stand of tetraploid fourwing saltbush (Atriplex canescens (Pursh) Nutt.) that had been browsed by cattle for at least 20 years. Tetraploid fourwing saltbush is sub-dioecious, with female, male, and monecious individuals occurring in fairly constant proportions (McArthur 1977, McArthur and Freeman 1982). At our research site on the Central Plains Experimental Range, Cibils et al. (2000) found that female shrubs were less abundant in browsed stands than in long-term exclosures. These authors also found that female shrubs in browsed stands were apparently younger than their male counterparts. Such apparent age differences, however, did not exist in stands that had received long-term protection from cattle. This evidence suggested that female shrubs at this site were being impacted more heavily by cattle-browsing than were male shrubs. Preferential browsing of female shrubs by cattle could have been responsible for this phenomenon. Our first hypothesis, therefore, 
was that female fourwing saltbush shrubs at our research site were being browsed more heavily than were male shrubs.

Since herbivory bias tends to disappear under either very low or very high herbivore densities (Boecklen et al. 1990, Danell et al. 1991), we manipulated stocking rates to test our second hypothesis that female-biased herbivory would tend to disappear under very low and very high grazing intensity (sensu Vallentine 1990) by cattle.

\section{Materials and Methods}

Our study site was located on the USDA-ARS Central Plains Experimental Range (CPER), approximately $60 \mathrm{~km}$ north-east of Fort Collins, Colo. $\left(40^{\circ} 49^{\prime} \mathrm{N}\right.$ $107^{\circ} 47^{\prime} \mathrm{W}$ ) at $1,650 \mathrm{~m}$ elevation. We conducted our experiments at a shrub-dominated site, on a floodplain area close to Owl Creek. Major soil types of our study site were Remmit loamy sands and Edgar loams. Fourwing saltbush, blue grama (Bouteloua gracilis (H.B.K.) Lag. ex Griffiths), and western wheatgrass (Agropyron smithii Rydb.) are the dominant plant species at the site (Liang et al. 1989). Mean annual precipitation is 320 $\mathrm{mm}$ (ranging from 150 to $500 \mathrm{~mm}$ ), 50 to $80 \%$ of which occurs between the months of May and September (Hart and Ashby 1998). Rainfall during and immediately before our experiments was above the historical average, particularly in 1997 (559 $\mathrm{mm})$. Late spring and summer rainfall (May-September) was also considerably higher in 1997 (436 mm) relative to 1996 (294 mm) and 1998 (275 mm).

Fourwing saltbush shrubs at our site at the CPER begin rapid growth in the month of May, flower during the month of June, and generally complete seed set by the end of August. Utricle maturity and shedding of current year's leaves occur in the month of October. Female shrubs exhibit mature utricles throughout the quiescent period that usually begins in November (Trlica et al. 1977).

To test the first and second hypotheses, we measured percent utilization of marked leaders on female and male fourwing saltbush shrubs in 0.5-ha experimental pastures. The pastures were built in 2 parallel blocks of 7 adjacent units each (one pasture was ungrazed in each block), within a pasture that had been moderately grazed by cattle in winter for approximately 20 years (approximately 5.3 ha $\mathrm{AUM}^{-1}$ over a 6month grazing season; $34 \mathrm{AU}$ days $\mathrm{ha}^{-1}$ ). Moderately grazed pastures at the CPER have historically been stocked to leave an ungrazed residue equal to $60 \%$ of peak standing crop (Hart and Ashby 1998).

Cattle diets on the shortgrass steppe change throughout the year as a consequence of seasonal variation in the quality and availability of dietary items (Schwartz and Ellis 1981, Shoop et al. 1985). In moderately stocked pastures with abundant fourwing saltbush, cattle diets contained 13 and $55 \%$ fourwing saltbush in November and March, respectively (Shoop et al. 1985). Therefore, shrubs are subjected to contrasting levels of utilization throughout a given year. We conducted 3 browsing experiments in 1997 and 1998: one in winter (January), another in early spring (April), and another in late summer (September). By repeating the experiment at different dates we were able to assess the impact of season (associated with plant phenology) on shrub utilization patterns.

Each experiment consisted of browsing 4 pastures with cattle (Hereford heifers weighing 400 to $520 \mathrm{~kg}$ ) for a period of 4 days. Two pastures were browsed moderately (4 heifers; 32 heifer days ha ${ }^{-1}$ ) and 2 were browsed heavily (12 heifers; 96 heifer days $\mathrm{ha}^{-1}$ ). Pastures were assigned randomly to each combination of season and stocking density at the beginning of the study. Randomization was performed within each block of experimental pastures, subject to the constraint that no 2 adjacent pastures were grazed on the same date. Cattle used in the experiments were randomly assigned to the 0.5 hectare pastures and were always taken from herds grazing pastures with abundant fourwing saltbush, to minimize dietary and social adjustment.

Twenty female and 20 male shrubs were randomly selected and labeled in each 0.5 ha grazing pasture. Each shrub was at least $3 \mathrm{~m}$ away from any other marked shrub, and was labeled by placing a numbered stake under the shrub crown, a marking technique inconspicuous to cattle. In the weeks prior to each experiment, 4 primary leaders were marked on each labeled shrub. On female shrubs we marked both reproductive (with utricles) and non-reproductive leaders. Lengths of marked leaders were measured prior to introducing the cattle. Immediately after each experiment we re-measured the lengths of marked leaders, and the base diameters and lengths of eaten secondary stems remaining on portions of utilized marked leaders.

Prior to each browsing event we harvested 30 primary and 30 secondary leaders, 15 from non-labeled female and 15 from non-labeled male shrubs in the experimental pastures. Each primary leader was labeled and sectioned into $6 \mathrm{~cm}$ long segments that were numbered sequentially from tip to base and placed in separate containers. Sectioned primary leaders were oven-dried separately at $60^{\circ} \mathrm{C}$ for 48 to 72 hours. Secondary stems were also labeled, placed in separate containers, and oven-dried in the same manner as were primary stems. We then recorded weights and lengths of the ovendried segments from each primary stem, and base diameter, weight and length of each oven-dried secondary stem. Primary stem segment measurements were transformed into cumulative relative (\%) expressions of length and biomass. Using linear regression we developed lengthweight relationships for each of the 30 primary leaders. Mean length-weight distribution of female $(n=15)$ and male $(n=15)$ stems were used to construct a lengthweight curve, later used to transform percent length measurements obtained in the field into percent biomass utilization estimates. A regression equation, relating total length of pooled male and female primary leaders (predictor) to their total biomass (response), was also developed to calculate biomass of marked primary stems when necessary. Secondary stem measurements were pooled and used to develop 2 regression equations: one relating base diameter (predictor) to stem length (response), and another relating stem length (predictor) to stem biomass (response). The first equation was used to estimate original length of eaten secondary stems. The second was used to estimate biomass of the length removed from utilized secondary stems. Length removed from a particular eaten secondary stem was calculated by subtracting the residual length measured in the field from the total estimated length (calculated using secondary stem base diameters measured with a dial caliper). Finally, total biomass removed from eaten secondary stems on a given marked primary leader was expressed as a percentage of its total estimated biomass. Thus, we obtained an overall estimate of utilization for each marked leader expressed in terms of percent biomass removed by cattle.

Mean percent utilization of marked leaders was calculated for each experimental pasture following each grazing trial. Data from each experiment were analyzed separately using repeated measures analysis of variance (ANOVAR). The statistical model selected for the analysis was a mixed effects repeated measures factori- 
al experiment design. Shrub gender (male and female), stocking density (moderate and heavy), year (1997 and 1998), and block (1 or 2) were the factors studied. Year was repeated within shrub gender, stocking density, and block. Shrub gender and stocking density were considered fixed effects. Block was considered a random effect. We included all possible 2way and 3-way interactions between fixed effects in the final model. We explored interactions between fixed and random main effects, and included significant interactions in the final model. The diagnostic plots of studentized residuals of raw utilization data showed slight deviations from the assumption of homogeneity of variances. We therefore arcsin-transformed our data and re-ran the residual diagnostic tests. The transformed data set did not exhibit any significant deviations from the ANOVA assumptions so all analyses were performed on the transformed data set. The overall level of significance was set at $\mathrm{P} \leq 0.05$. We used proc GLM and proc MIXED from the SAS Version 6.12 (1996) package to perform the statistical analyses.

We calculated herbivory bias for each treatment at each of the experiment dates $(n=12)$ by subtracting mean utilization of marked leaders on male shrubs from that of females. We then calculated the Pearson Correlation Coefficient ( $r$ ) and performed linear regression analysis (Ott 1993) using mean overall utilization of marked leaders and herbivory bias as the independent and dependent variables, respectively. We used proc CORR and proc GLM from the SAS Version 6.12 (1996) package to perform the statistical analysis. The level of significance used to test statistical hypotheses regarding the regression model and the slope of the function $\left(\beta_{1}\right)$ was set at $\mathrm{P} \leq 0.05$.

\section{Results}

In relation to the first hypothesis, utilization of marked leaders on female shrubs was significantly higher than that of male shrubs in January and September (Fig. 1). In April, no significant gender bias in shrub herbivory was observed (Fig. 1). Overall shrub utilization was greater in the snowy winter of 1997 than in the mild winter of 1998 , probably because understory vegetation was covered in 1997 . In all 3 experiments there were significant differences in overall utilization of shrubs between years and stocking density treatments; heavily stocked pastures exhibited consistent overall higher shrub utilization
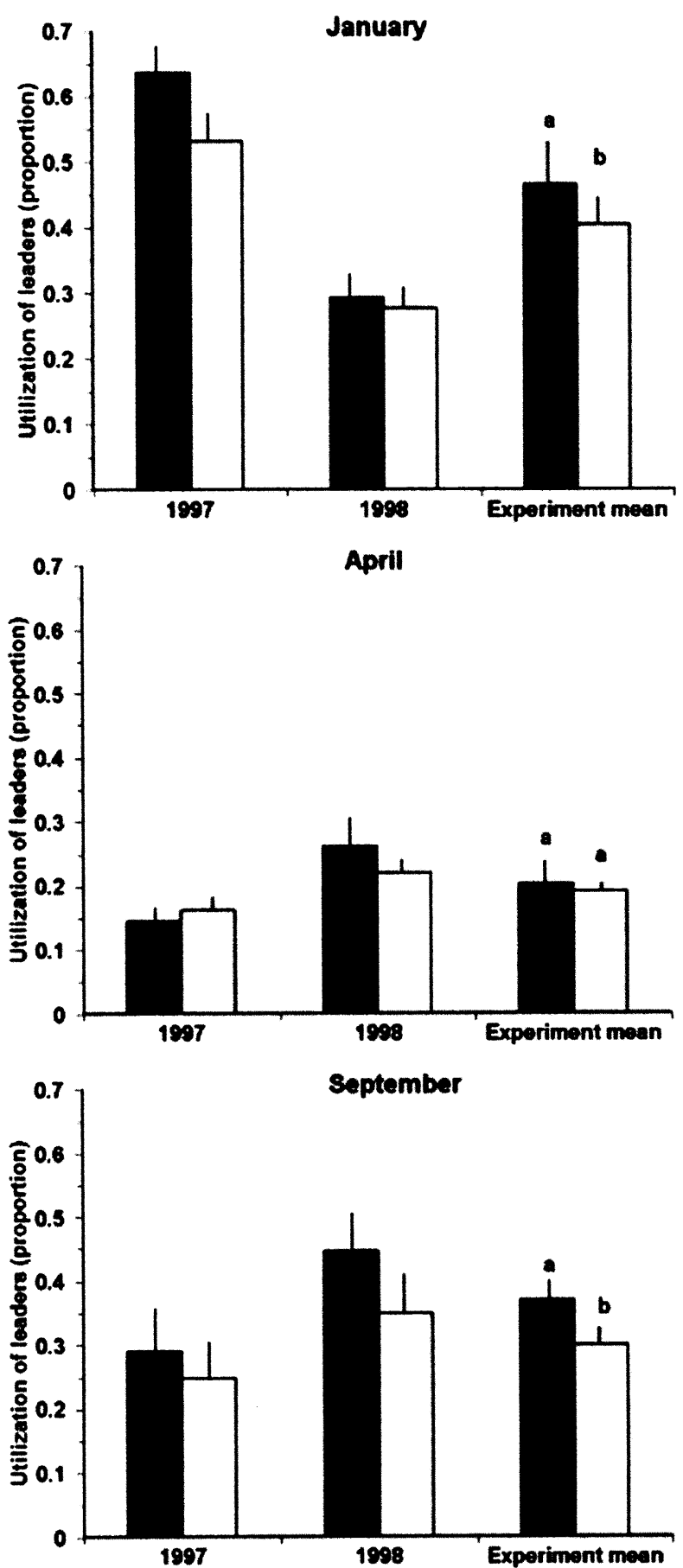

Fig 1. Mean utilization of marked leaders on female (solid bars) and male (empty bars) shrubs in: January (Winter), April (early Spring), and September (late Summer). Different letters indicate significantly different means $(P=0.05)$. Error bars indicate standard errors of means $(n=2)$.

levels (Table 1). Shrub gender, however, affected utilization significantly, irrespective of stocking density, in 2 (January and September) of the 3 experiments.

In relation to the second hypothesis, female biased browsing increased as overall shrub utilization increased $(\mathrm{r}=0.82, \mathrm{P}$
$=0.01$, Fig. 2). The gender-biased browsing pattern tended to disappear when overall shrub utilization was low. Contrary to what we had hypothesized, sex-biased herbivory persisted under the highest levels of utilization imposed by our experimental treatments. 
Table 1. Overall utilization of marked leaders in moderate and heavy stocking density treatments.

\begin{tabular}{lcccc}
\hline \hline & & & & \\
Month & Moderate & Heavy & Moderate & Heavy \\
\hline January & $45.9 \mathrm{~b}^{1}$ & $70.9 \mathrm{a}$ & $20.7 \mathrm{~b}$ & $36.3 \mathrm{a}$ \\
April & $11.6 \mathrm{~b}$ & $19.1 \mathrm{a}$ & $17.9 \mathrm{~b}$ & $30.3 \mathrm{a}$ \\
September & $10.0 \mathrm{~b}$ & $43.9 \mathrm{a}$ & $23.3 \mathrm{~b}$ & $56.3 \mathrm{a}$ \\
\hline
\end{tabular}

${ }^{1}$ Different letters within a row and year indicate significantly different means $(P=0.05)$.

\section{Discussion and Conclusions}

Cattle browsed female fourwing saltbush shrubs more intensely than male sirrubs both in winter and late summer. Utilization of female and male shrubs was similar in early spring. Cattle exhibited consistent preferences across stocking density treatments and years. While our results depart from the general pattern of male-biased herbivory found in the literature, they are consistent with findings from most studies of large herbivores grazing dioecious plants (Williams et al. 1978, Graetz 1978, Maywald 1998). Sheep preferentially browse female shrubs of bladder saltbush (Atriplex vesicaria Heward ex. Benth.) irrespective of season or phenological stage (Maywald 1998). This pattern apparently results in higher mortality of female shrubs that leads to alterations of shrub sex ratios (Williams et al. 1978). Our results, however, agree only partially with a recent study conducted with sheep in a transplant garden with male and female fourwing saltbush shrubs (Maywald et al. 1998). Similarly to our findings, in late winter (March), a date roughly equivalent to our early spring (April) experiment, these authors found no sex-related differences in shrub biomass removal. However, during flowering in late spring (June), Maywald et al. (1998) reported that sheep consumed significantly more biomass from male shrubs as compared to females.

When overall shrub utilization by cattle was low (in April), possibly because new green herbaceous vegetation was available, we did not detect any gender-related bias in herbivory irrespective of stocking density. The female-biased pattern became more pronounced under increasing levels of overall shrub utilization by cattle. It is possible that the highest level of utilization imposed by our experiments (in January 1997) was not sufficient to alter cattle preferences and cause the herbivorybias to disappear, as suggested by studies conducted with other herbivores (Danell et al. 1991).

Differences in overall levels of shrub utilization by cattle between years were possibly influenced by weather fluctuations. Overall utilization in the January experiment $(58 \%$ and $28 \%$ in 1997 and 1998 , respectively) apparently reflected weather-driven variations in understory forage availability. A heavy snowfall reduced grass availability severely during our January experiment in 1997. Conversely, a mild winter of 1998 with abundant grass residue from the previous

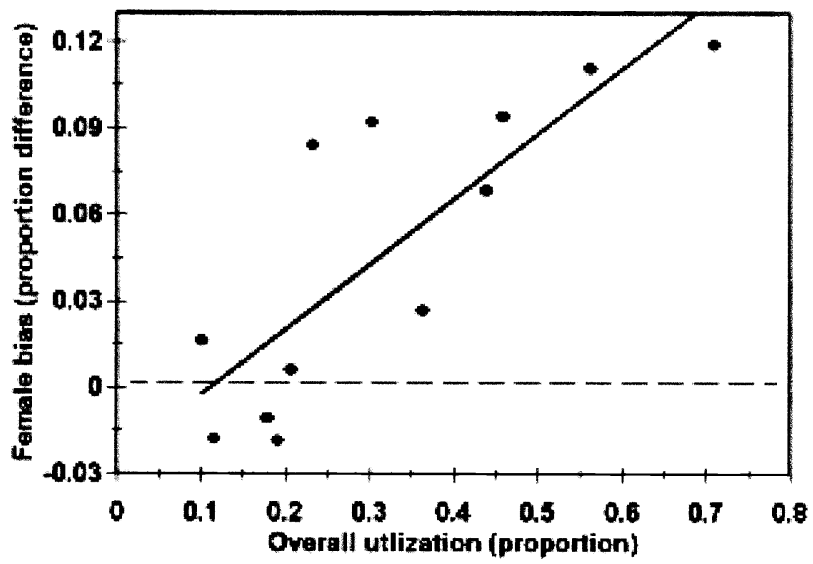

Fig 2. Female bias in utilization of marked leaders (female utilization - male utilization) in relation to overall level of shrub utilization. Points above the horizontal line indicate female bias, points below the horizontal line indicate male bias. growing season (a particularly moist summer in 1997) was associated with higher levels of understory availability and lower shrub utilization. A somewhat similar pattern occurred in the September experiment; the very high summer rainfall of 1997 (436 mm) compared with the relatively dry summer of 1998 (275 mm) had a visible effect on understory growth presumably producing contrasting browsing levels $(27 \%$ and $40 \%$ shrub utilization in 1997 and 1998, respectively). In April, between-year variations in shrub utilization $(15 \%$ and $24 \%$ in 1997 and 1998 , respectively) may have been related to differences in the onset of cool-season grass and forb growth. Thus, overall browsing pressure on fourwing saltbush in our experiments appeared to be inversely related to understory forage availability.

Heavy defoliation or continuous grazing can promote mortality in fourwing saltbush stands (Cibils et al. 1998 and references therein). For example, single browsing events involving the removal of $100 \%$ of current year's growth led to high fourwing saltbush mortality rates (37 to $100 \%$ ) over a 5-year period in an experiment conducted in Israel (Benjamin et al. 1995). At our research site, fourwing saltbush shrubs can take 14 to 26 months to recover from a single heavy artificial defoliation event involving the removal of $90 \%$ of current year's growth (Trlica et al. 1977). If defoliation occurs in August (near maturity) or if shrubs are subjected to multiple defoliations, recovery may take even longer (Trlica et al. 1977). Because cattle in our experiments removed woody stems from previous growing seasons together with current year's growth, our utilization estimates were based on total (primary) leader biomass. Therefore, removal of current year's growth at dates when shrub utilization was highest (January 1997 and September 1998), particularly in the case of the heavier-browsed female shrubs, was possibly comparable to levels of defoliation known to promote shrub mortality. Additionally, since females of dioecious plant species generally grow slower than their male counterparts (Jing and Coley 1990), female shrubs may need more time than males to recover from a defoliation event (Cibils et al., unpublished data), and would consequently be more vulnerable to future defoliations. Therefore, it would be reasonable to expect higher mortality in the slower-growing female shrubs subjected to higher levels of defoliation. Differences in shrub utilization levels between years in our experiments suggest that heavy browsing events in moderately 
stocked pastures do not occur every year. Consequently, mortality rates of shrubs (females, in particular) can be expected to be less severe than those described by Benjamin et al. (1995).

Although the study of palatability factors influencing female-biased browsing patterns was beyond the scope of this study, preliminary data on nitrogen content of leaves and thin stems of female and male shrubs at our site (Cibils et al. unpublished data) suggest that differences in $\mathrm{N}$ content were possibly not important in driving cattle preferences in our experiments. Fourwing saltbush can synthesize carbon-based secondary compounds such as triterpenoid saponins (Nord and Van Atta 1960, Sanderson et al. 1987) and oxalates (Davis 1981). Saponins, common in many genera of the Chenopodiaceae (Cibils et al. 1998 and references therein), can deter herbivores, and have been shown to influence patterns of herbivory in stands of fourwing saltbush (Otsyina 1983, Sanderson et al. 1987). Utricle bracts of fourwing saltbush can contain large concentrations of saponins, $10 \%$ of the weight of original bract chaff (Nord and Van Atta 1960). Preliminary observations of withinshrub browsing patterns in our experiments suggest that cattle preferred to consume non-flowering stems when browsing female shrubs (Cibils et al. unpublished data). It would be reasonable to speculate that gender-specific differences in levels of defensive compounds (mainly saponins) may have been responsible for the browsing pattern we observed, however further studies on aspects of the defensive ecology of fourwing saltbush will be needed to test these hypotheses.

Differences in fourwing saltbush sex ratios between exclosures and adjacent grazed pastures previously reported at our site (Cibils et al. 2000) may have been the result of greater mortality rates in female shrubs. Female-biased browsing by cattle may have promoted larger mortality of females relative to males, thus altering sex ratios and promoting gender-specific age differences.

\section{Literature Cited}

Alliende, M.C. 1989. Demographic studies of a dioecious tree. II The distribution of leaf predation within and between trees. J. Ecol. 77:1048-1058.

Benjamin, R.W., Y. Lavie, M. Forti, D. Barkai, R. Yonatan, and Y. Hefetz. 1995. Annual regrowth and edible biomass of two species of Atriplex and of Cassia sturtii after browsing. J. Arid Environ. 29:63-84
Boecklen, W.J. and T. M. Hoffman. 1993. Sex-biased herbivory in Ephedra trifurca: the importance of sex-by-environment interactions. Oecologia 96:49-55.

Boecklen, W.J., P.W. Price, and S. Mopper. 1990. Sex and drugs and herbivores: Sexbiased herbivory in arroyo willow (Salix lasiolepis). Ecol. 71:581-588.

Cibils, A.F., D.M. Swift, and R.H. Hart. 2000. Gender-related differences of shrubs in stands of Atriplex canescens with different histories of grazing by cattle. J. Arid Environ. 46:383-396.

Cibils, A.F., D.M. Swift, and E.D. McArthur, 1998. Plant-herbivore interactions in Atriplex: current state of knowledge. Gen. Tech. Rep. RMRS-GTR-14. U.S. Dept. of Agr., Forest Serv., Rocky Mountain Res. Station. Ogden, Ut.

Danell, K., T. Elmqvist, L. Ericson, and A. Salmonson. 1985. Sexuality in willows and preference by bark-eating voles: defense or not? Oikos 44:82-90.

Danell, K., J. Hjalten, L. Ericson, and T. Elmqvist. 1991. Vole feeding on male and female willow shoots along a gradient of plant productivity. Oikos 62:145-152.

Davis, A.M. 1981. The oxalate, tannin, crude fiber, and crude protein composition of young plants of some Atriplex species. J. Range Manage. 34:329-331.

Graetz, R.D. 1978. The influence of grazing by sheep on the structure of a saltbush (Atriplex vesicaria Hew ex Benth.) population. Australian Rangel. J. 1:117-125.

Hart, R.H. and M.M. Ashby. 1998. Grazing intensities, vegetation, and heifer gains: 55 years on shortgrass. J. Range Manage. 51:392-398.

Hjalten, J. 1992. Plant sex and hare feeding preferences. Oecologia 89:253-256.

Jing, S. and P. Coley. 1990. Dioecy and herbivory: the effect of growth rate on plant defense in Acer negundo. Oikos 58:369-377.

Krischik, V.A. and R.F. Denno. 1990. Patterns of growth, reproduction, defense and herbivory in the dioecious shrub Baccharis halimifolia (Compositae). Oecologia 83:182-190.

Liang, Y.M., D.L. Hazlett, and W.K. Lauenroth. 1989. Biomass dynamics and water use efficiencies of five plant communities in the shortgrass steppe. Oecologia 80:148-153.

Lovett Doust, J. and P.B. Cavers. 1982. Sex and gender dynamics in jack-in-the-pulpit, Arisaema triphyllum (Araceae). Ecol. 63:797-808.

Lovett Doust, J. and L. Lovett Doust. 1985. Sex ratios, clonal growth and herbivory in Rumex acetosella, p. 327-339. In: J.White (ed.), Studies on plant demography: a festchrift for John Harper. Academic Press, London.

Maywald, D. 1998. Palatability variation between the sex phenotypes of bladder saltbush (Atriplex vesicaria). - Ph.D. Diss., Univ. of Adelaide, Adelaide, Australia.
Maywald, D.L., E.D. McArthur, G.L. Jorgensen, R. Stevens, and S.C. Walker. 1998. Sex biased palatability variation in fourwing saltbush (Atriplex canescens). J. Range Manage. 51:650-654.

McArthur, E.D. 1977. Environmentally induced changes of sex expression in Atriplex canescens. Heredity 38:97-103.

McArthur, E.D. and D.C. Freeman. 1982. Sex expression in Atriplex canescens: Genetics and environment. Bot. Gaz. 143:476-482.

Nord, E.C. and G.R. Van Atta. 1960. Saponin- a seed germination inhibitor. Forest Sci. 6:350-353.

Otsyina, R.M. 1983. Evaluation of shrubs as native supplements to cured crested wheatgrass (Agropyron desertorum) pasture for sheep. Ph.D. Diss., Utah State Univ., Logan, Ut.

Ott, R.L. 1993. An introduction to statistical methods and data analysis, $4^{\text {th }}$ Edition. Duxbury Press, Belmont.

SAS Institute. 1996. SAS/base and SAS/stat software. SAS Institute Inc. Cary, N.C.

Sanderson, S.C., R.L. Pendelton, E.D. McArthur, and K.T. Harper. 1987. Saponin effect on small mammal forage preference in a planting of Atriplex canescens, $\mathrm{p}$. 74-77. In: Provenza F.D., Flinders, J.T., and McArthur, E.D. (Comps.). Proc. Symposium on Plant-Herbivore Interactions; Gen. Tech. Rep. INT-222. U.S. Dept. of Agr., Forest Serv., Intermount. Res. Station. Ogden, Ut.

Schwartz, C.C. and J.E. Ellis. 1981. Feeding ecology and niche separation in some native and domestic ungulates on the shortgrass prairie. J. App. Ecol. 18:343-353.

Shoop, M.C., R.C. Clark, W.A. Laycock and R.M. Hansen. 1985. Cattle diets on shortgrass ranges with different amounts of fourwing saltbush. J. Range Manage. 38:443-449.

Trlica, J., M. Buwai, and J. Menke. 1977. Effects of rest following defoliations on the recovery of several range species. J. Range Manage. 30:21-27.

Vallentine, J.F. 1990. Grazing Management. Academic Press, New York, N.Y.

Watson, M.A. 1995. Sexual differences in plant developmental phenology affect plantherbivore interactions. TREE 10:180-182.

Williams, D.G., D.J. Anderson, and K.R. Slater. 1978. The influence of sheep on pattern and process in Atriplex vesicaria populations for the Riverine Plain of New South Wales. Australian J. Bot. 26:381-392. 